\title{
ANALISIS STRATEGI PENGEMBANGAN BISNIS UMKM MOESLEM SQUARE NGAWI
}

\author{
Andi Triyawan, Amin Fitria \\ Universitas Darussalam Gontor \\ e-mail: anditriyawan@unida.gontor.ac.id,aminfitria@gontor.ac.id
}

\begin{abstract}
The Aim of this research are to determine the strategy of the Moeslem Square MSME business development of the big family of Mr. H. Ahmad Subkhi Djuwigna and to know Islamic business ethics in the business development strategy of the big family Mr. H. Ahmad Subkhi Djuwigna. The Business of Mr. H. Ahmad Subkhi Djuwigna is a fast growing business in Muslim fashion products that are external and internal strategies of business development. The branch of bussiness like Aluminum and Glass Mabrur along with its branches, mabrur boutiques, as-salaam boutiques, kalila boutiques, and nirmala boutiques that have been known by many people in the city of Ngawi. This is because this business has a very Islamic development method and its own characteristics and always provides the best quality of goods and services for its customers. This research is a qualitative descriptive study. This research was conducted in a business location in order to obtain data using primary data sources through interviews, observation and documentation, and to support this research also used secondary data taken from books, journals and other sources related to Islamic business ethics in business development strategies extended family Mr. H. Ahmad Subkhi Djuwigna. In the business development strategy there are external factors, namely economic, social, demographic culture, environment, government, technology and competitors. In addition there are internal factors in the strategy like management, marketing, finance, products and Human Resourse
\end{abstract}

Keywords : Development strategy, Business, Internal factor, External factor

Abstrak : Penelitian ini bertujuan untuk mengetahui strategi pengembangan bisnis UMKM Moeslem Square keluarga besar Bapak H. Ahmad Subkhi Djuwigna dan mengetahui etika bisnis Islam dalam strategi pengembangan bisnis keluarga besar Bapak H. Ahmad Subkhi Djuwigna. Bisnis Keluarga besar Bapak H. Ahmad Subkhi Djuwigna adalah bisnis yang berkembang pesat dalam produk busana muslim yang strategi pengembangan bisnis dari segi eksternal dan internal. Mabrur alumunium dan kaca beserta cabangnya, butik mabrur, butik as-salaam, butik kalila, dan butik nirmala yang sudah dikenal oleh banyak masyarakat di kota Ngawi. Hal ini dikarenakan usaha ini memiliki cara pengembangan yang sangat islami dan ciri khas tersendiri dan selalu memberikan kualitas barang serta pelayanan terbaik untuk konsumennya. Penelitian ini merupakan penelitian deskriptif kualitatif. Penelitian ini dilakukan dilokasi usaha guna mendapatkan data yang menggunakan sumber data primer melalui wawancara, observasi dan dokumentasi, serta untuk mendukung penelitian ini digunakan pula data sekunder yang diambil dari buku-buku, jurnal dan sumber lainnya yang berkaitan dengan etika bisnis Islam dalam strategi pengembangan bisnis keluarga besar Bapak H. Ahmad Subkhi Djuwigna. Dalam strategi pengembangan bisnis terdapat faktor eksternal yaitu ekonomi, sosial, budaya demografi, lingkungan, pemerintah, teknologi dan competitor. Selain itu terdapat faktor internal dalam strategi yaitu manajemen, pemasaran, keuangan, produk dan SDM.

Kata kunci : Strategi pengembangan, Faktor Internal, Faktor Eksternal

\section{A. PENDAHULUAN}

Usaha mikro, kecil, dan menengah (UMKM) menjadi salah satu pilar pemenuhan target pencapaian potensi digital dalam roadmap $e$ commerce Indonesia untuk menggali potensi digital ekonomi USD 130 miliar hingga tahun 2020. Sejalan dengan arahan Presiden Republik Indonesia Joko Widodo, Kementerian Komunikasi dan
Informatika (Kominfo) pun memiliki program untuk mendorong UMKM agar go digital. Targetnya hingga akhir tahun 2020, sudah ada 6 juta UMKM yang sudah go digital. Menurut riset Deloitte tahun 2016, dari 57,9 juta UMKM di Indonesia (berdasarkan data Kementerian Koperasi \& UMKM, tahun 2015) ternyata hanya 9 persen dari pelaku yang 
serius menggunakan internet untuk menjual produknya dengan jejaring sosial yang terintegrasi maupun menggunakan platform e-commerce. Yang menarik ternyata masih ada 36 persen lainnya yang sama sekali tidak memiliki akses internet baik melalui komputer ataupun ponsel pintar smartphone. ${ }^{1}$

Data itu menunjukkan mindset UMKM belum selaras dengan perkembangan teknologi. Padahal, penelitian Bank Dunia menyebut, keterlibatan UMKM secara digital menjadi salah satu pendorong pencapaian target pertumbuhan ekonomi 7 persen di tahun 2025. Mendorong UMKM menjadi lebih digital pun akan menjaga ketahanan UMKM Indonesia dan produk nasional di tengah mulainya Masyarakat Ekonomi ASEAN (MEA), free trade agreement dan kedatangan e-commerce global yang membawa UMKM dari negara lain. Dengan memadukan sistem penjualan online dan offline pada bisnis UMKM, akan menjadi langkah yang bagus untuk menjangkau lebih banyak konsumen. Program UMKM go digital yang dicanangkan Kominfo pun bertujuan untuk membuka peluang pasar baru bagi UMKM di Indonesia baik di ranah regional maupun global, dimana peluang ini dapat memperluas basis konsumen mereka untuk meningkatkan penjualan.
Pada tahun 2018 akan ada 350 juta pengguna internet di Asia Tenggara. Para pengguna internet ini berpotensi untuk melakukan transaksi perdagangan secara online e-commerce dengan nilai mencapai USD 30 - 40 miliar atau sekitar Rp 390 - 540 triliun. Sementara menurut data Statista.com, nilai transaksi ecommerce di seluruh dunia pada tahun 2016 lalu telah mencapai USD 1.915 miliar atau sekitar Rp24.895 triliun. Dan pada tahun 2020, angka tersebut diperkirakan naik dua kali lipat menjadi USD 4.058 miliar. $^{2}$

Di Indonesia sendiri, transaksi online di tahun 2015 telah mencapai $\mathrm{Rp}$ 200 triliun, dan pada akhir tahun 2020 akan meningkat sembilan kali lipat menjadi Rp 1.850 triliun. Besarnya potensi transaksi secara online inilah yang diharapkan dapat mendorong kesejahteraan rakyat Indonesia. Pasalnya dari PDB Indonesia yang pada 2016 lalu mencapai Rp12.406,8 triliun, sekitar 55,6 persennya berasal UMKM. Jika target pemerintah berhasil mendorong 6 juta UMKM tahun 2020, maka porsi UMKM yang memiliki kemampuan e-commerce akan meningkat dari 8 persen saat ini menjadi 10-12 persen. Akibatnya kontribusi UMKM terhadap PDB di tahun 2020 akan bertambah 12 persen menjadi sekitar 67,6 persen. Hal ini tentu

\footnotetext{
${ }^{2}$ Ibid.,
} 
sejalan dengan program Nawacita poin ke

6 yaitu meningkatkan produktivitas rakyat dan daya saing di pasar internasional. Program UMKM go digital ditujukan sebagai akselerator pertumbuhan ekonomi nasional dan pengembangan kapasitas UMKM. ${ }^{3}$

"It is hard to overstate the importance of reputation in a market economy. Even more important is the reputation of the corporation it self as seen through the eyes of outsiders. It is an exceptionally important market value that in principle is on a balance sheet as goodwill."4

Seperti kita tahu bahwa UMKM di Indonesia kini kian banyak dan semua reputasi suatu bisnis terdapat pada mata konsumen dari luar. Dan yang sangat terpenting memberi yang terbaik kepada pasar dan masyarakat. ${ }^{5}$ Karena tidak hanya di perkotaan tetapi hingga menjelajahi tempat perdesaan. Dari berbagai macam usaha banyak sekali masyarakat Indonesia yang sangat berminat dalam berbisnis. Mulai dari bisnis kecil-kecilan, warung, toko, rumah makan, hingga bisnis online. Semua berlomba lomba dalam persaingan bisnis. Hal tersebut sangat mengagumkan sekali bagi bangsa Indonesia. Dalam

\footnotetext{
${ }^{3}$ Ibid.,

${ }^{4}$ Kutipan dari Roger W. Hutt, Reputation on the line: the starbucks cases, Journal International of Business Strategy, Vol. 37 Issue: 1, Emerald Group Publishing Limited, hlm. 19

${ }^{5}$ Ibid.,
}

perkembangan bisnis offline Indonesia bisa disebut merupakan prospek pasar yang cerah bagi para investor. Telah banyak para pebisnis sukses Indonesia yang berhasil. Dapat dilihat seperti Tung Dasem Waringin, Abdurizal Bakrie yang telah mencapai sebuah keuntungan yang sangat besar. ${ }^{6}$

Seorang pemilik dan pengelola bisnis keluarga berusaha untuk meraih kesuksesan, terutama dari segi profit, namun ia mengalami kegagalan. Bagi pemikiran utilitarian, tindakan si pebisnis ini tergolong tidak baik karena tanpa hasil yang baik. Tetapi, kegagalan dalam memulai bisnis tetap dinilai baik karena di balik kegagalan itu terdapat hikmah atau pelajaran hidup yang diraih. Dalam pemikiran deontologis, ketaatan pada prinsip dan aturan yang benar akan membawa kemanfaatan yang jauh lebih besar daripada sekedar profit atau hasil yang diraih dengan melanggar aturan atau tanpa prinsip. ${ }^{7}$

Demikian pula dalam bisnis keluarga. Keluarga yang sejahtera bisa diraih melalui kegiatan bisnis yang selalu memperhatikan prinsip dan aturan. Profit yang diraih dengan melanggar aturan perpajakan bisa membawa kekawatiran

${ }^{6}$ Perkembangan bisnis di Indonesia dalam dekade terakhir, diposkan oleh Agness Ness di 02.15, http//blog.argado.com/2010/05.

Augustinus Simanjuntak, Keadilan Bisnis dalam Ketenagakerjaan, Jurnal Manajemen Dan Kewirausahaan, Vol.1 2, No. 2, September 2010, hlm.113-114. 
dan kecemasan dalam hidup. Apalagi dalam bisnis yang tidak didasari dengan strategi yang baik akan mengabaikan resiko-resiko yang akan dihadapi nantinya.

Dalam suatu bisnis UMKM yang ada, terlihat sangat mengembangkan segala faktor yang dipunya untuk meningkatkan profit, produk, dan pemasaran, sampai tersebar luas di dalam negeri maupun luar negeri. Padahal hal ini tidak cukup untuk memperkuat apa yang didapatkan nantinya, apabila kita melalaikan pokok dari Agama Islam yaitu lillahi ta'ala.

Penelitian yang dilakukan oleh LB. Ruth Florida W. M. Hutabarat 2015. Memakai peran dari ke-3 aktor penggerak dalam Triple Helix yaitu : a) Pihak Akademisi; b) Pihak Pebisnis; c) Pihak Pemerintah. Yang mana didalamnya tidak terdapat aspek etika bisnis Islam, yang seharusnya selalu ditanamkan dalam suatu bisnis. Yaitu dalam segi Tauhid, Nubuwwah, 'Adalah, Khilafah, dan Ma'ad, hal inilah yang akan menjadi suatu patokan dalam Etika Bisnis Islam, dan mempengaruhi barokahnya suatu bisnis seperti penelitian yang saya tulis. ${ }^{8}$

Berbeda dengan penelitian yang dilakukan oleh Tio Wahyu Nugrooho dan Dina Novia Priminingtyas 2016. Untuk

${ }^{8}$ LB. Ruth Florida W. M. Hutabarat, Strategi Pengembangan Usaha Kuliner di Kota Malang Berbasis Ekonomi Kreatif, JESP-Vol. 7, No 1 Maret 2015, hlm. 20 menguji pengaruh budaya organisasi dan dampak peningkatan kinerja karyawan. Hasil analisis menunjukkan bahwa terjadinya peningkatan kapasitas produksi rata-rata kecap Cemara dari tahun 20142015 menandakan terjadinya pertumbuhan positif perusahaan dan merupakan indikator semakin meningkatnya eksistensi produk Kecap Cemara. Dan dalam penelitian yang saya tulis untuk menguji dari segi strategi Internal dan eksternal. Dari segi internal yaitu manajemen perusahaan, pemasaran, keuangan, produk, dan sumber daya manusia. Sedangkan dari segi eksternal yaitu ekonomi, social, budaya demografi, lingkungan, pemerintah, teknologi dan kompetitor. $^{9}$

Penelitian yang dilakukan oleh Endang Sri Winarni 2006. UKM yang memanfaatkan sumber permodalan eksternal dari bank. Alasan UKM belum memanfaatkan kredit bank sebagian besar adalah faktor kebijakan dan persyaratan perbankan. Sedangkan dalam penelitian yang saya tulis dalam pengembangan bisnis, tidak bergantung pada bank, modal dalam bisnis Moslem Square Ngawi diambil dari usaha yang telah digeluti sebelumnya. Dalam pengambilan hutang bank sangat diminimalisir,

${ }^{9}$ Tio Wahyu Nugrooho dan Dina Novia Priminingtyas, Strategi Pengembangan Usaha Kecap Cemara Dengan Metode Blue Ocean Strategy dan Balanced Scorecard Pada UKM Cemara Food, Kecamatan Talun Kabupaten Blitar, Jurnal Habitat, Volume 27, No. 1, April 2016, hlm. 13 
dikarenakan terikat dengan bank akan memberatkan bila pinjaman bertambah terus menerus. Jadi di tanamkan kepada keluarga bapak Ahmad Subkhi Djuwigna dengan berdikari. ${ }^{10}$

Padahal sejarah menunjukkan kepada kita bahwa sebagian besar para nabi berlatar belakang pebisnis. Nabi Daud misalnya, dikenal sebagai pengrajin berbahan baku daun kurma, menurut satu riwayat Hasyam bin Urwah dari ayahnya disebutkan bahwa ketika Nabi Daud berkhutbah, tanpa rasa sungkan mereka mengatakan dirinya sebagai pengrajin daun kurma untuk dibuat keranjang atau lainnya. $^{11}$

Banyak produk baru yang gagal di pasaran karena satu masalah sederhana, yaitu konsumen tidak menginginkan produk tersebut. Maka perusahaan berkewajiban melakukan pengembangan produk atas dasar permintaan pasar. Sehubungan dengan fenomena bisnis tersebut, Kalila Moslem Square, telah melakukan inovasi produksi, mengantisipasi perubahan dan dinamika bisnis, dengan melakukan riset pasar, mengidentifikasi peluang usaha, keinginan dan harapan konsumen sebagai langkah awal dalam inovasi produksi. ${ }^{12}$

${ }^{10}$ Endang Sri Winarni, Strategi Pengembangan Usaha Kecil Melalui Peningkatan Aksesibilitas Kredit Perbankan, Infokop Nomor 29 Tahun XXII, 2006.

${ }^{11} \mathrm{Ibid}, \mathrm{hlm} .3$.

12 Wawancara dengan Clara Nadia Putri, manager Kalila Moslem Square mewakili Ownership,
Penelitian ini dilakukan untuk memahami, mendeskripsikan dan menganalisis Strategi Pengembangan Bisnis UMKM menurut Etika Bisnis Islam.

\section{B. METODE PENELITIAN}

Penelitian ini merupakan penelitian deskriptif kualitatif. Penelitian ini dilakukan pada lokasi usaha guna mendapatkan data yang menggunakan sumber data primer melalui wawancara, observasi dan dokumentasi. Dalam rangka mendukung kedalaman analisis, penelitian ini juga menggunakan pula data sekunder yang diambil dari bukubuku, jurnal dan sumber lainnya yang berkaitan dengan etika bisnis Islam

\section{HASIL DAN PEMBAHASAN}

\section{Strategi Pengembangan Bisnis UMKM Moeslem Square}

Salah satu dari cara pengembangan bisnis adalah pada pemasaran dan ini berlangsung setiap lahirnya. Berjalannya pengembangan bisnis, sebagai kegiatan khusus. Diprediksi kegiatan pemasaran benar sebagai sebuah LHD pada lembaga Komersial sebagai ukuran lembaga lingkungan pengembangan bisnis. Dari lembaga komersial berdasarkan faktor yang mana dia akan melakukannya. Mempengaruhi aktif strategi komersial pengembangan

bertempat di Kalila Moslem Square. 
bisnis.

Data eksternal dikumpulkan untuk menganalisis hal-hal yang menyangkut persoalan ekonomi, sosial, budaya, demografi, lingkungan, politik, pemerintah, hukum, teknologi, persaingan dalam pasar industri, serta data eksternal relevan lainnya.

\section{Faktor Eksternal dalam bisnis UMKM}

\section{a. Ekonomi}

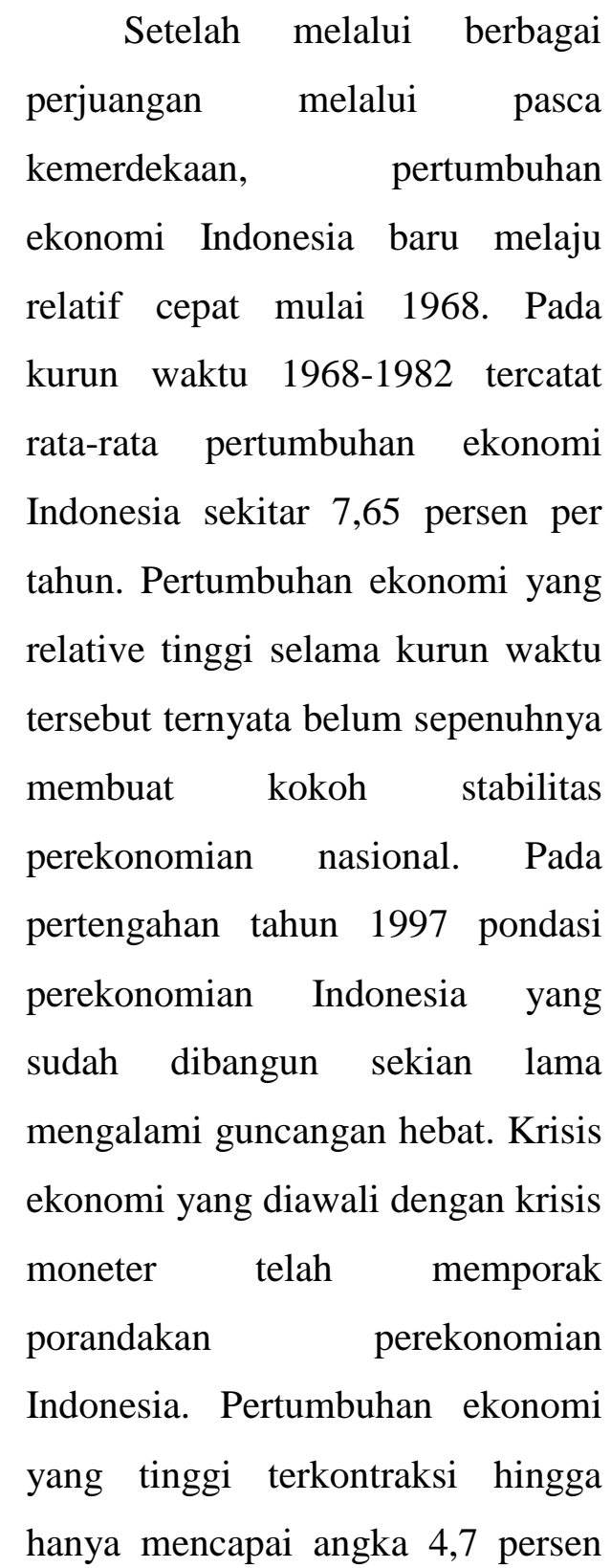

pada tahun 1997, kemudian merosot tajam menjadi sekitar 13,1 persen pada tahun 1998. Krisis ini juga berimbas pada indikator makro lainnya seperti inflasi yang meningkat hingga 78 persen. Tingkat pengangguran juga meningkat signifikan akibat semakin minimnya lapangan pekerjaan dan PHK masal beberapa perusahaan dan industry yang berhenti beroperasi karena tingginya biaya produksi akibat depresiasi rupiah.

UMKM Moeslem Square Ngawi ini telah memberi gaji setiap pekerjanya dengan nominal lebih tinggi daripada UMR (Upah Minimum Regional), dan hal ini diakui oleh kantor ketenagakerjaan. Mengapa demikian, dikarenakan beliau sangatlah kekeluagaan dalam soal kesejahteraan. Bila bisa memberi lebih kenapa tidak, karena Allah maha tahu dan Raaziq.

\section{b. Lingkungan}

Analisis lingkungan ini meliputi dari kegiatan memonitor, evaluasi, dan mengumpulkan informasi dari lingkungan eksternal dan internal perusahaan. Tujuannya yaitu untuk mengidentifikasi faktor strategis, elemen eksternal dan internal akan 
memutuskan strategi dimasa yang akan datang bagi perusahaan.

Semua rintisan seluruh keluarga besar Bapak H. Ahmad Subkhi Djuwigna ini berawal dari beliau yang memilih lokasi hingga mambangunnya. Sampai bila diberi sesuatu beliau tidak mau karena agar mereka berusaha dan bila beliau masih bisa mencari maka beliau tidak mau menerima agar ada usaha dulu sampai berkembang. Beliau sangat mendidik dalam usaha anakanaknya dan mendukung sampai pemilihan tempat juga terpilih sangat strategis.

Lingkungan yang tidak pasti akan mempersulit manajer untuk memprediksi lingkungan bisnis. Menurut Milikie dalam Listeria ketidakpastian dapat diartikan sebagai rasa ketidakmampuan individu dalam memprediksi lingkungannya secara tepat. Tingginya ketidakpastian lingkungan organisasi dapat menyulitkan perusahaan dalam menyusun perencanaan dan pengendalian yang efektif. Hal ini akan berpengaruh pada kualitas sistem informasi akuntansi manajemen perusahaan yang telah terstruktur. Melalui perbaikan akan terus menerus dilakukan sampai sistem ini dapat melakukan tugasnya dalam manajemen.

\section{c. Sosial}

Dalam pemasaran Bapak $\mathbf{H}$. Ahmad Subkhi Djuwigna sejak dulu sampai sekarang belum pernah memakai sistem online. Dan hal ini dilaksanakan sesuai sunnah rosul yaitu lapangan dan hal ini sangat mendorong silaturrahmi terhadap masyarakat. Beliau selalu menunggu pelanggan dan melayaninya.

1) Tanggung jawab sosial perusahan penting disamping etika, karena tanggung jawab perusahaan menjembatani komitmen individu dan kelompok dalam lingkungan perusahaan. Syarat penting tanggung jawab social perusahaan, meliputi:

2) Tindakan dilakukan dengan sadar dan tahu. Dilakukan oleh pribadi yang rasional, kemampuannya sudah matang dan berfungsi secara nirmal.

3) Adanya kebebasan, tidak dalam keadaan tertekan.

4) Manajer mau dan bersedia melakukan tindakan. Manajer mempunyai principle of alternate possibilities, artinya 
jika masih ada alternative

baginya untuk bertindak secara lain, tidak dalam keadaan terpaksa.

5) Tanggung jawab sosial perusahaan meliputi: tanggung jawab terhadap lingkungan dan ramah lingkungan.

Memperhatikan dan melestarikan lingkungan dengan mendaur ulang limbah dan menjalin komunikasi yang baik dengan masyarakat.

\section{d. Budaya Demografi}

Orientasi pasar sebagai budaya organisasi yang paling efektif dalam menciptakan perilaku penting untuk penciptaan nilai unggul bagi pembeli serta kinerja dalam bisnis. ${ }^{13}$ Interior pada Kalila dan Nirmala semua itu kreativitas anak-anak dengan gaya baru di zaman modern ini. Bapak $\mathbf{H}$.

Ahmad Subkhi Djuwigna tidak bisa ikut campur dalam hal interior, karena itu memang ilmu anak-anak muda. Beliau sebagai orang tua hanya bisa mendukung dan mendorong bila ada apa-apa, contohnya butuh apa-apa nanti beliau bantu dan diambilkan bila

${ }^{13}$ Mieke Supranoto, Strategi menciptakan keunggulan bersaing produk melalui orientasi pasar, inovasi, dan orientasi kewirausahaan dalam rangka meningkatkan kinerja pemasaran ( Studi empiris pada: Industri Pakaian Jadi Skala Kecil dan Menengah di kota Semarang ), hlm. 20 butuh dan bisa beliau beri. Dan hal ini mengikuti budaya dan hal-hal modern. ${ }^{14}$

\section{e. Teknologi}

Strategi komunikasi sangat di butuhkan dalam perencanaan komunikasi dengan manajemen komunikasi untuk mencapai tujuan yang telah di tentukan. Strategi komunikasi harus dilakukan, dalam arti kata bahwa pendekatannya bisa berbeda sewaktu-waktu bergantung pada situasi dan kondisinya. Komponen-komponen dalam strategi komunikasi terdiri dari : komunikator, pesan, media, khalayak dan efek serta tujuan yang hendak di capai oleh komunikator. Tujuan komunikasi itu perlu dinyatakan secara tegas sebelum pelaksanaan komunikasinya, sehingga jelaslah siapa khalayak sasaran (target audience) dan siapa pula kelompok sasarannya (target group). Namun di dalam penentuan target audience dan target group tantangannya berkaitan dengan beberapa aspek, seperti sosiologis, psikologis, politis dan ekonomis. ${ }^{15}$

${ }^{14}$ Wawancara dengan Bapak H. Ahmad Subkhi Djuwigna, pemilik Usaha Keluarga mabrur 1, 2, 3, mabrur collection, kalila, nirmala dan the drink kalila, bertempat di Mabrur 2 Ngawi 16.00, hari Rabu, 18/4/2018.

${ }^{15}$ Mokhamad Mahfud, Strategi Komunikasi Integrasi Interkoneksi Dalam Meningkatkan Kualitas Skripsi Mahasiswa (Studi Pada Dosen Program Studi Ilmu Komunikasi Fakultas Ilmu Sosial dan 
Dilain sisi Strategi Komunikasi

adalah

rujukan

dari

communication

planning

(perencanaan komunikasi)

sekaligus

communication

management atau manajemen

untuk mencapai sasaran/goal yang

di harapkan. Untuk mencapai

tujuan tersebut strategi komunikasi

harus mampu menunjukkan

langkah-langkah operasionalnya

secara taktis, dalam arti kata bahwa

pendekatan (approach) bisa

berbeda-beda sewaktu tergantung

dari situasi dan kondisi. Strategi

komunikasi sangat di butuhkan

dalam perencanaan komunikasi

dengan manajemen komunikasi

untuk mencapai tujuan yang telah

di tentukan. Strategi komunikasi

harus dilakukan, dalam arti kata

bahwa pendekatannya bisa

berbeda sewaktu-waktu bergantung

pada situasi dan kondisinya.

Komponen-komponen dalam

strategi komunikasi terdiri dari :

komunikator, pesan, media,

khalayak dan efek serta tujuan

yang hendak di capai oleh

komunikator. Tujuan komunikasi

itu perlu dinyatakan secara tegas

sebelum

pelaksanaan

Humaniora UIN Sunan Kalijaga Yogyakarta), Dosen Prodi Ilmu Komunikasi UIN Sunan Kalijaga, Vol. 08 No.01 April 2015, hlm. 5 komunikasinya, sehingga jelaslah siapa khalayak sasaran (target audience) dan siapa pula kelompok sasarannya (target group). Namun di dalam penentuan target audience dan target group tantangannya berkaitan dengan beberapa aspek, seperti sosiologis, psikologis, politis dan ekonomis. ${ }^{16}$

Dalam peningkatannya dalam teknologi social media tidak memakainya, lebih memilih langsung sesuai sunnah rosul sebagai mu'amalah. Dan untuk meningkatkan silaturrahmi satu sama lain. ${ }^{17}$

Untuk penggunaan barkot toko bangunan sangat banyak itemnya, jadi sangat sulit untuk pemakaian barkot dalam item ribuan sangat luar biasa. Pernah memakai barkot tapi sangat repot sekali dengan harga bangunan yang tidak stabil akan banyak merubah harga di barkot dan membuat sulit. Tetapi untuk semua butik baju muslimah sudah memakai komputerisasi

\footnotetext{
${ }^{16}$ Mokhamad Mahfud, Strategi Komunikasi
} Integrasi Interkoneksi Dalam Meningkatkan Kualitas Skripsi Mahasiswa (Studi Pada Dosen Program Studi Ilmu Komunikasi Fakultas Ilmu Sosial dan Humaniora UIN Sunan Kalijaga Yogyakarta), Dosen Prodi Ilmu Komunikasi UIN Sunan Kalijaga, Vol. 08 No.01 April 2015, hlm. 4

${ }^{17}$ Wawancara dengan H. Ahmad Subkhi Djuwigna, pemilik Usaha Keluarga mabrur 1, 2, 3, mabrur collection, kalila, nirmala dan the drink kalila, bertempat di Mabrur 2 Ngawi 16.00, hari Rabu, 18/4/2018. 
semua. Disemua toko dan butik sudah dilengkapi CCTV untuk menjaga kepercayaan, dan menghindari kemudharatan. Semua ini pasti ada baiknya untuk keamanan dalam hal yang tidak diduga nantinya. ${ }^{18}$

Dalam penggunaan AC semua toko dan butik telah memakainya, seperti kita tahu bahwa di Kalila terdapat 16 AC, Nirmala terdapat 12 AC, As-Salaam terdapat 12 AC, dan dimabrur pun juga terdapat $\mathrm{AC}$ disana. Hal ini kita lengkapi demi kenyamanan konsumen nantinya. Melihat di zaman modern ini beliau sangat memikirkan kepuasan konsumen agar percaya dengan pelayanan dan kenyamanan penjualan di produk beliau.

Mendukung pencapaian sasaran bisnis pelanggan dengan memahami bisnis menjamin keamanan produk, memberi kualitas yang dipilih, memberikan inovasi produk dan layanan yang memuaskan pelanggan. ${ }^{19}$ Menyediakan layanan disain,

${ }^{18}$ Wawancara dengan $\mathrm{Hj}$. Ema $\mathrm{S}$, pemilik Usaha Keluarga mabrur 1, 2, 3, mabrur collection, kalila, nirmala dan the drink kalila, bertempat di Gontor Putri 2 via telephon 09.00, hari Rabu, $14 / 4 / 2018$

${ }^{19}$ Wawancara dengan Bapak H. Ahmad Subkhi Djuwigna, pemilik Usaha Keluarga mabrur 1, 2, 3, mabrur collection, kalila, nirmala dan the drink kalila, bertempat di Mabrur 2 Ngawi 16.00, hari Rabu, 18/4/2018. percetakan, pengemasan dan layanan distribusi yang paling disukai pelanggan untuk mencerahkan dan mencerdaskan masyarakat. $^{20}$

\section{f.Kompetiror}

Bapak H. Ahmad Subkhi Djuwigna tidak pernah berkompetisi, karena semua yang menganggap hal ini kompetisi akan timbulnya saingan tidak sehat nantinya. Beliau menyerahkan semuanya kepada Allah dengan tawakal dan berdoa, karena hanyalah Allah yang maha memberi. Kepada anak-anak beliau selalu menasehati tidak usah iri, ingin ini ingin itu dan tergiur, karena semua sudah diatur oleh Allah, rezeki dari Allah, dan segalanya itu datang dari Allah. ${ }^{21}$

\section{Faktor Internal dalam bisnis UMKM}

\section{a. Pengembangan}

Tidak pernah berkompetisi, karena semua yang menganggap hal ini kompetisi akan timbulnya

${ }^{20}$ Goldie Gunadi, Dana Indra Sensuse, Penerapan Metode Data Mining Market Basket Analysis terhadap data penjualan Produk Buku dengan Algoritma Apriori dan Frequent Pattern Growth, Studi Kasus Percetakan PT. Gramedia, Jurnal Telematika MKOM, Vol.4 No.1, Maret 2012,Ilmu Komputer Universitas Indonesia, hlm. 6

${ }^{21}$ Wawancara dengan Bapak H. Ahmad Subkhi Djuwigna, pemilik Usaha Keluarga mabrur 1, 2, 3, mabrur collection, kalila, nirmala dan the drink kalila, bertempat di Mabrur 2 Ngawi 16.00, hari Rabu, 18/4/2018. 
saingan tidak sehat nantinya. Beliau menyerahkan semuanya kepada Allah dengan tawakal dan berdoa, karena hanyalah Allah yang maha memberi. Kepada anak-anak beliau selalu menasehati tidak usah iri, ingin ini ingin itu dan tergiur, karena semua sudah diatur oleh Allah, rezeki dari Allah, dan segalanya itu datang dari Allah. ${ }^{22}$

\section{b. Manajemen}

Dalam tahapan manajemen strategik saling memiliki interaksi dan timbal balik dari tahap pertama hingga akhir. Manajemen Strategik ini dapat dilihat sebagai suatu prosesyang meliputi sejumlah tahapan yang saling berkaitan dan berurutan. Proses manajemen strategik bersifat dinamis dan Analisis Lingkungan Formulasi Strategi Implikasi Strategi Evaluasi dan control merupakan sekumpulan komitmen, keputusan, dan aksi yang diperlukan suatu perusahaan atau organisasi untuk mencapai strategic competitiveness dan menghasilkan keuntungan diatas rata-rata. Dari tahapan proses manajemen strategik tersebut, maka dapat disimpulkan bahwa manajemen strategik merupakan sekumpulan keputusan dan tindakan yang menghasilkan perumusan dan implementasi rencana yang didesain untuk mencapai tujuan suatu perusahaan. Manajemen strategik melibatkan pengambilan keputusan jangka panjang yang berorientasi masa depan serta rumit dan membutuhkan cukup banyak sumber daya, maka partisipasi manajemen puncak sangat penting. Dengan pendekatan manajemen strategik, manajer pada semua tingkatan perusahaan berinteraksi dalam perencanaan dan implementasinya. Sebagai akibatnya, konsekuensi perilaku manajemen strategik serupa dengan pengambilan keputusan partisipatif. $^{23}$

Dalam keluarga besar Bapak $\mathbf{H}$. Ahmad Subkhi Djuwigna tidak ada struktur dengan organisasi yang mendetail, karena semua terstruktur oleh keluarga yang memegang satu sama lain. Jadi semua dipegang sendiri-sendiri. Kalila anak pertama
${ }^{22}$ Wawancara dengan Bapak H. Ahmad Subkhi Djuwigna, pemilik Usaha Keluarga mabrur 1, 2, 3, mabrur collection, kalila, nirmala dan the drink kalila, bertempat di Mabrur 2 Ngawi 16.00, hari Rabu, 18/4/2018.
${ }^{23}$ Aan Novianto, Analisis Strategi Pengembangan Bisnis (Studi Pada Industri Kerajinan Gerabah Desa Negara Ratu Kecamatan Natar) hlm. 35 
Mbak Pipip dan Nirmala anak kedua yaitu Mbak Putri. ${ }^{24}$

Dalam pemegang manajemen semua sendiri-sendiri dari setelah diberi tanah dan dibangunkan, lalu diisi dan dikelola sendiri. Maka hal ini sangat baik untuk dikembangkan sendiri. Tapi bila butuh modal lebih, maka beliau memberi saran bahwa di Indonesia ini banyak yang membina UMKM dan hal ini juga harus dibatasi dalam peminjamannya, kurang lebihnya cukup untuk pengembangan usaha. Jadi dalam manajemen Ibu Ema berada di Mabrur 2 depan di Ndungus, Mabrur Collection di Dr Soeroto, dan As-Salaam di Yos Sudarso. Dan Bapak H. Ahmad Subkhi Djuwigna membawahi manajemen Mabrur 2 Ndungus yang belakang yaitu Alumunium dan kaca dan bengkel, Mabrur 1 Klitik dan 3 di Dr Soetomo. Jadi beliau pun tidak tahu tentang manajemen yang di bawahi ibu, beliau membagi tugas dengan istri agar rapi. ${ }^{25}$

\section{c. Pemasaran}

${ }^{24}$ Wawancara dengan Mbak Pipip, pemilik manajemen kalila dan the drink kalila, bertempat di Gontor Putri 2 Ngawi, via telephone 16.00, hari Rabu, 18/4/2018.

${ }^{25}$ Wawancara dengan Bapak H. Ahmad Subkhi Djuwigna, pemilik Usaha Keluarga mabrur 1, 2, 3, mabrur collection, kalila, nirmala dan the drink kalila, bertempat di Mabrur 2 Ngawi 16.00, hari Rabu, 18/4/2018.
Perusahaan yang memiliki kompetensi dalam bidang pemasaran, manufacturing, dan inovasi dapat menjadikannya sebagai sumber - sumber untuk mencapai keunggulan bersaing. Melalui ketiga bidang kompetensi tersebut, perusahaan dapat mengembangkan strategi sehingga dapat menghasilkan produk laku di pasaran. Sedangkan pengertian kedua menekankan pada keunggulan dalam pencapaian kinerja selama ini. Pengertian ini terkait dengan posisi perusahaan dibandingkan dengan apa pesaingnya. Perusahaan yang terus memperhatikan perkembangan kinerjanya dan berupaya untuk meningkatkan kinerja tersebut memilki peluang mencapai posisi persaingan yang baik maka sebenarnya perusahaan telah memilki modal yang kuat untuk terus bersaing dengan perusahan lain. $^{26}$

Kompetensi kewirausahaan dibutuhkan didalam implementasi strategi pemasaran agar diperoleh keunggulan bersaing yang mantap melalui nilai responsifitas atas kebutuhan pelanggan. Sedangkan jiwa kewirausahaan sendiri 
meliputi 5 hal, yakni: otonomi, keinovatifan, pengambilan risiko, proaktivitas, dan agresifitas kompetitif.

Pemasaran entrepreneurial merupakan sebuah konsep yang terpadu diera penuh perubahan seperti sekarang ini. ${ }^{27}$

\section{d. Keuangan}

Penilaian yang akurat mengenai dampak dari formulasi strategi terhadap kinerja organisasi tidak hanya memerlukan kriteria evaluasi keuangan, tetapi juga non keuangan pengukuran dampak berbasis perilaku. ${ }^{28}$

Anggaran adalah pernyataan dari program perusahaan dalam kondisi keuangan. Dalam anggaran digunakan perencanaan dan kontrol anggaran, supaya anggaran dapat diketahui secara detail berapa besarnya biaya yang dibutuhkan dari suatu program. ${ }^{29}$

Pertukaran dapat terjadi antara pengusaha dengan karyawan. Pengusaha berperan sebagai pemasar dan karyawan berperan sebagai pelanggan atau konsumen. Praktek pertukaran di dalam perusahaan seperti ini menggambarkan proses pemasaran. Dalam sebuah rumah tangga, orang hlm. 30

\footnotetext{
${ }^{27}$ Mieke Supranoto, Strategi menciptakan...,
}

${ }^{28}$ Aan Novianto, Analisis Strategi ... hlm.36

${ }^{29}$ Ibid, hlm. 42 tua juga dapat berperan sebagai pemasar dan anak berperan sebagai pelanggan. Pertukaran yang saling menguntungkan membuat pelanggan cenderung loyal pada pemasar yang sama. Sebagai pemasar, lembaga keagamaan juga menggantungkan kelangsungan hidupnya pada jamaahnya. Dukungan dari jamaah sangat diperlukan selamanya. ${ }^{30}$

Pengelolaan uang semua diserahkan kepada Ibu Ema dan Bapak H. Ahmad Subkhi Djuwigna tidak mau tahu jadi sudah saling percaya. Tetapi herannya Bank sangat mempercayai Mabrur untuk meminjamkan uangnya. Sampai setiap hari ditelphon untuk meminjamkan uang, sampai bank Danamon sampai bilang untuk tidak diberi tanggungan. Tetapi Bapak H. Ahmad Subkhi Djuwigna yang namanya meminjam pasti harus mengganti, tetapi kalau tidak butuh akan mubadzir namun jika dibutuhkan mabrur bilang sendiri. ${ }^{31}$

\footnotetext{
${ }^{30}$ Prof. Dr. Basu Swastha Dharmmesta,
} M.B.A, Peran Pemasaran dalam Perusahaan dan Masyarakat, Modul Manajemen Pemasaran, hlm.

${ }^{31}$ Wawancara dengan Bapak $H$. Ahmad Subkhi Djuwigna, pemilik Usaha Keluarga mabrur 1, 2, 3, mabrur collection, kalila, nirmala dan the drink kalila, bertempat di Mabrur 2 Ngawi 16.00, hari Rabu, 18/4/2018. 
Dalam keluarga ini terdapat rasa kekeluargaan terhadap karyawannya, dari segi kesejahteraan pun juga. Keluarga ini telah banyak memberi motor kepada karyawannya, dalam hal ini tidak lupa juga bila ada rezeki lebih dishodaqohkan. Sampai keluarga ini memberi inventaris rumah tangga yang membutuhkan. Semua terasa sebagai keluarga, karena telah bersama dari karyawankaryawannya anak jalanan hingga mempunyai anak semua. Seperti yang memegang Mabrur Collection telah lama dengan ibu Hj. Ema S. ${ }^{32}$

\section{e. Produk}

Dalam melakukan inovasi produk ada tiga hal penting yang harus diperhatikan yaitu keunggulan produk, keunikan produk, keunikan produk, serta biaya produk. Produk inovasi dapat gagal karena banyak alasan. Kesalahan dalam menerapkan strategi menjadi sebab yang sering terjadi, sebab lainnya antara lain desain produk yang tidak inovatif, salah memperkirakan persaingan, masalahnya terletak pada desain atau biaya produksinya jauh lebih

\footnotetext{
${ }^{32}$ Wawancara dengan Ibu Sun, pekerja terpercaya Ibu $\mathrm{Hj}$. Ema $\mathrm{S}$, mabrur collection, bertempat di Mabrur Collection Ngawi 09.00, hari Jum'at, 13/4/2018.
}

tinggi dari yang diperkirakan. ${ }^{33}$

Perusahaan akan mencapai kepuasan konsumen dengan meningkatkan kualitas produk melalui perencanaan strategi bisnis yang sempurna. Untuk menciptakan strategi bisnis yang sempurna, diperlukan perbaikan secara terus menerus. Prosses ini menandakan bahwa manajemen tidak serta merta melakukan perencanaan strategi yang bagus akan tetapi tetap berusaha untuk memperbaikinya dengan evaluasi dan tindak lanjut. ${ }^{34}$

Bahan bangunan itu relative kalau ada pembangunan sangat ramai, tapi kalau alumunium dan kaca itu banyak alat-alat rumah tangga itu laris apalagi almarialmari. Kusen-kusen juga sangat diminati, karena selalu diperlukan untuk rumah tangga atau hadiahhadiah.

Untuk butik-butik semua produk diambil dari Jakarta, jadi di butik Mabrur, As-salaam, Kalila, dan

${ }^{33}$ Mieke Supranoto, Strategi menciptakan keunggulan bersaing produk melalui orientasi pasar, inovasi, dan orientasi kewirausahaan dalam rangka meningkatkan kinerja pemasaran ( Studi empiris pada: Industri Pakaian Jadi Skala Kecil dan Menengah di kota Semarang ), hlm. 28

${ }^{34}$ Uum Helmina Chaerunisak, Eko Widodo Lo, Pengaruh Ketidakpastian Lingkungan dan Strategi Bisnis terhadap Sistem Informasi Akuntansi Manajemen dengan Total Quality Manajemen sebagai Variabel Intervening, Sekolah Tinggi Ilmu Ekonomi Yayasan Keluarga Pahlawan Negara Yogyakarta, Akuntansi Dewantara Vol. 1 No. 2 Oktober 2017, hlm. 5 
Nirmala produknya tidak akan sama dengan toko-toko di Ngawi ini. Jadi Bapak H. Ahmad Subkhi

Djuwigna mengantar sendiri ke Jakarta karena ibu Ema harus memilih sendiri yang bagus-bagus, tidak bisa diserahkan ke orang lain. $^{35}$

Pengembangan produk adalah strategi yang berupaya meningkatkan penjualan dengan memperbaiki atau memodifikasi produk/jasa yang sudah ada. Pengembangan produk biasanya memerlukan biaya yang besar untuk penelitian dan pengembangan. Lima hal yang bisa dijadikan pedoman kapan sebaiknya menerapkan strategi pengembangan produk secara efektif, yaitu : Ketika organisasi mempunyai produk sukses yang mencapai tahap kematangan dalam daur hidupnya; idenya adalah menarik para pelanggan yang puas untuk mencoba produk produk baru (yang lebih baik) karena mereka memiliki pengalaman positif dengan produk atau jasa organisasi saat ini. Ketika organisasi bersaing dalam industri dimana

${ }^{35}$ Wawancara dengan Bapak H. Ahmad Subkhi Djuwigna, pemilik Usaha Keluarga mabrur 1, 2, 3, mabrur collection, kalila, nirmala dan the drink kalila, bertempat di Mabrur 2 Ngawi 16.00, hari Rabu, 18/4/2018. perkembangan teknologi terjadi sangat cepat. Ketika para pesaing utama menawarkan produk dengan mutu lebih baik dan harga yang sebanding. Ketika organisasi bersaing dalam industri yang tumbuh cepat. Ketika organisasi mempunyai kemampuan penelitian dan pengembangan yang sangat kuat $^{36}$

Beberapa indikator yang digunakan untuk menilai inovasi adalah daya kreatifitas, inovasi teknis, perubahan desain, perubahan system distribusi, dan sistem administrasi pembayaran. Inovasi teknis adalah inovasi pada proses perusahaan dalam menghasilkan produk. Perubahan desain adalah kemampuan perusahaan untuk menghasilkan produk sesuai keinginan pelanggan. Daya kreatifitas adalah kemampuan perusahaan untuk menciptakan atau mengembangkan ide - ide baru. Perubahan sistem distribusi adalah upaya perusahan untuk mengembangakan sarana distibusi yang tepat. Sistem administrasi pembayaran adalah upaya perusahaan untuk membuat system pembayaran administrasi yang

\footnotetext{
${ }^{36}$ Aan Novianto, Analisis Strategi Pengembangan Bisnis (Studi Pada Industri Kerajinan Gerabah Desa Negara Ratu Kecamatan Natar), hlm.33
} 
sesuai dengan keinginan

pelanggan. $^{37}$

Beberapa indikator yang digunakan untuk mengukur keunggulan bersaing adalah keunikan, jarang dijumpai, tidak mudah ditiru, tidak mudah diganti, dan harga bersaing. Keunikan produk adalah keunikan produk perusahaan yang memadukan nilai seni dengan selera pelanggan. Harga bersaing adalah kemampuan perusahaan untuk menyesuaikan harga produknya dengan harga umum di pasaran. Tidak mudah dijumpai berarti keberadaannya langka dalam persaingan yang saat ini dilakukan. Tidak mudah ditiru berarti dapat ditiru dengan tidak sempurna. Sulit digantikan berarti tidak memiliki pengganti yang sama $^{38}$

\section{f.Sumber Daya Manusia}

Karyawan yang dibina adalah anak-anak yang nakal, contohnya drop dari SD dan SMP atau anakanak jalanan. Karena anak-anak yang nakal semakin banyak bakat terpendam, contohnya Mas Haris suami anak pertama Mbak Pipip. Dulu nakal dan setelah dibina sangat banyak sekali bakat hlm. 29

\footnotetext{
${ }^{37}$ Mieke Supranoto, Strategi menciptakan...,
}

${ }^{38}$ Ibid, hlm. 22 terpendam. Sampai sekarang juga banyak pekerja yang dari berdirinya toko hingga sekarang. Sekarang sudah mempunyai anak. Sampai ada kantor yang datang untuk melihat gaji pekerja. Beliau memberi bukunya dan memang sudah diatas UMR (Upah Minimum Regional) dan akhirnya heran. Karena beliau memakai metode kekeluargaan, bila ada beliau memberi motor dari banyak pekerja. Diberi inventaris bila ada yang kurang. ${ }^{39}$

Kesejahteraan karyawan juga ada yaitu liburan bersama karyawan ke Yogyakarta contohnya. Jadi refresing bersama, dan kali ini pada ingin ke Bali tapi menabung untuk mendapatkannya.

Dalam pendidikan Islam terhadap karyawan juga sangat ditekankan, semua karyawan wanita harus menggunakan hijab, tidak hanya itu tetapi juga melaksanakan kewajiban sebagai muslim. ${ }^{40}$

Kendala pasti ada dan itu relative, selama kendala itu diserahkan kepada Allah SWT,

${ }^{39}$ Wawancara dengan Bapak H. Ahmad Subkhi Djuwigna, pemilik Usaha Keluarga mabrur 1, 2, 3, mabrur collection, kalila, nirmala dan the drink kalila, bertempat di Mabrur 2 Ngawi 16.00, hari Rabu, 18/4/2018.

${ }^{40}$ Wawancara dengan Ibu Erna, pekerja terpercaya Ibu $\mathrm{Hj}$. Ema $\mathrm{S}$, mabrur collection, bertempat di Mabrur 2 Ngawi 09.00, hari Jum'at, 13/4/2018. 
maka insyaallah akan seminimal mungkin kedala itu ada. Pernah di toko besi dan bangunan beliau mengangkat pekerja dari anak-anak jalanan, dan ketika itu membawa motor beliau pergi, ketika dicari Alhamdulillah ditemukan. Bukan malah dimarahi atau dipenjara, malah dengan Bapak H. Ahmad Subkhi Djuwigna dibelikan motor baru. ${ }^{41}$

\section{KESIMPULAN}

Terbukti bahwa di dalam usaha keluarga besar Bapak H. Ahmad Subkhi Djuwigna Ngawi, tertanam dengan baik. Terbukti dengan diwajibkannya karyawan berbusana muslim khususnya wanita, mewajibkan sholat lima waktu walaupun ketika jam kerja, dan disiapkannya tempat sholat yang nyaman. Karena sholat adalah tiang agama. Senyum sapa salam juga ditanamkan dalam pelayanannya setiap ada yang datang.

Tidak hanya itu keluarga beliau juga menanamkan jihad fisabilillah dengan ibadah yang sunnah pula yaitu sholat duha, tahajud, tasbih, istikhoroh, karena selagi bisa melaksanakan mari melaksanakan semuanya agar selalu dekat dengan Allah SWT. Ini di

${ }^{41}$ Wawancara dengan Bapak H. Ahmad Subkhi Djuwigna, pemilik Usaha Keluarga mabrur 1, 2, 3, mabrur collection, kalila, nirmala dan the drink kalila, bertempat di Mabrur 2 Ngawi 16.00, hari Rabu, 18/4/2018. tanamkan pula kepada anak-anaknya yang telah membawahi manajemen butik Kalila, dan butik Nirmala.

Kejujuran juga ditanamkan agar suatu kepercayaan tercipta dalam kegiatan jual beli yang termasuk sunnah rosul ini, karena hal ini mempererat silaturrahmi. Dalam penawaran produk juga harus jujur didalamnya. Dan bila telah percaya maka akan semakin datang untuk waktu setelahnya.

Dalam maslahah pelanggan beliau juga tidak lupa penggunaan teknologi untuk memudahkan kegiatan jual beli. Dari segi barcode, kartu member, setiap butik, dan AC setiap tokonya juga tesedia senyaman mungkin, agar pelanggan puas dan semakin nyaman dalam berbelanja. Tidak hanya itu di butik dan the drink kalila juga bisa memesan secara online atau jalur pribadi.

Semua tertata rapi dengan interior yang baik dan unik tidak lupa disisipkan hal-hal yang Islami seperti quotes-quotes muslim di butik dah café. Setiap hari raya muslim juga diberi berita muslim yang berkaitan pada member di social media, dan mengganti baju di mannequin dengan baju yang berkaitan dengan hari itu, sehingga menarik para pelanggan. Tidak lupa shodaqoh juga diterapkan didalamnya, terutama pada keluarga dan karyawan. 


\section{DAFTAR PUSTAKA}

Aan Novianto, Analisis Strategi Pengembangan Bisnis (Studi Pada Industri Kerajinan Gerabah Desa Negara Ratu Kecamatan Natar)

Augustinus Simanjuntak, Keadilan Bisnis dalam Ketenagakerjaan Jurnal Manajemen Dan Kewirausahaan, Vol.1 2, No. 2, September 2010

Dr. Muhammad Syafi'I Aritonio, M.EC, Bisnis syari' ah dari nol, Langkah jitu menuju kaya, penuh berkah dan bermakna, Dr. Muhammad Syafi'I Aritonio, M.EC, hikmah (PT Mizan Publika) anggota IKAP, Sitinajma 2007

Endang Sri Winarni, Strategi Pengembangan Usaha Kecil Melalui Peningkatan Aksesibilitas Kredit Perbankan, Infokop Nomor 29 Tahun XXII, 2006.

Goldie Gunadi, Dana Indra Sensuse, Penerapan Metode Data Mining Market Basket Analysis terhadap data penjualan Produk Buku dengan Algoritma Apriori dan Frequent Pattern Growth, Studi Kasus Percetakan PT. Gramedia, Jurnal Telematika MKOM Vol.4 No.1, Maret 2012,Ilmu Komputer Universitas Indonesia

Kompas. 2017. 05 September 2017, http://www.kompas.com.htm

LB. Ruth Florida W. M. Hutabarat, Strategi Pengembangan Usaha Kuliner di Kota Malang Berbasis Ekonomi Kreatif, JESP-Vol. 7, No 1 Maret 2015

Mieke Supranoto, Strategi menciptakan keunggulan bersaing produk melalui orientasi pasar, inovasi, dan orientasi kewirausahaan dalam rangka meningkatkan kinerja pemasaran ( Studi empiris pada: Industri Pakaian Jadi Skala Kecil dan Menengah di kota Semarang )
Mokhamad Mahfud, Strategi Komunikasi Integrasi Interkoneksi Dalam Meningkatkan Kualitas Skripsi Mahasiswa (Studi Pada Dosen Program Studi Ilmu Komunikasi Fakultas Ilmu Sosial dan Humaniora UIN Sunan Kalijaga Yogyakarta), Dosen Prodi Ilmu Komunikasi UIN Sunan Kalijaga, Vol. 08 No.01 April 2015

Mokhamad Mahfud, Strategi Komunikasi Integrasi Interkoneksi Dalam Meningkatkan Kualitas Skripsi Mahasiswa (Studi Pada Dosen Program Studi Ilmu Komunikasi Fakultas Ilmu Sosial dan Humaniora UIN Sunan Kalijaga Yogyakarta), Dosen Prodi Ilmu Komunikasi UIN Sunan Kalijaga, Vol. 08 No.01 April 2015

Prof. Dr. Basu Swastha Dharmmesta, M.B.A, Peran Pemasaran dalam Perusahaan dan Masyarakat, Modul Manajemen Pemasaran

Roger W. Hutt, Reputation on the line: the starbucks cases, Journal International of Business Strategy, vol. 37 Issue: 1, Emerald Group Publishing Limited

Tio Wahyu Nugrooho dan Dina Novia Priminingtyas, Strategi Pengembangan Usaha Kecap Cemara Dengan Metode Blue Ocean Strategy dan Balanced Scorecard Pada UKM Cemara Food, Kecamatan Talun Kabupaten Blitar, Jurnal Habitat, Volume 27, No. 1, April 2016

Uum Helmina Chaerunisak, Eko Widodo Lo, Pengaruh Ketidakpastian Lingkungan dan Strategi Bisnis terhadap Sistem Informasi Akuntansi Manajemen dengan Total Quality Manajemen sebagai Variabel Intervening, Sekolah Tinggi Ilmu Ekonomi Yayasan Keluarga Pahlawan Negara Yogyakarta, Akuntansi Dewantara Vol. 1 No. 2 Oktober 2017 
Veny Ari Sejati, Strategi Periklanan Pada

Bisnis Retail, Jurnal Komunikasi

ASPIKOM, Fakultas Ilmu Sosial dan

Ekonomi Universitas Respati

Yogyakarta, Volume 2 Nomor 4, Januari 2015

Wawancara dengan Bapak H. Ahmad Subkhi Djuwigna, pemilik Usaha Keluarga mabrur 1, 2, 3, mabrur collection, kalila, nirmala dan the drink kalila, bertempat di Mabrur 2 Ngawi 16.00, hari Rabu, 18/4/2018

Wawancara dengan Bapak $\mathrm{Hj}$. Ema S, pemilik Usaha Keluarga mabrur 1, 2, 3 , mabrur collection, kalila, nirmala dan the drink kalila, bertempat di Gontor Putri 2 via telephon 09.00, hari Rabu, 14/4/2018

Wawancara dengan Ibu Erna, pekerja terpercaya Ibu $\mathrm{Hj}$. Ema S, mabrur collection, bertempat di Mabrur 2 Ngawi 09.00, hari Jum'at, 13/4/2018

Wawancara dengan Ibu Sun, pekerja terpercaya $\mathrm{Ibu} \mathrm{Hj}$. Ema $\mathrm{S}$, mabrur collection, bertempat di Mabrur Collection Ngawi 09.00, hari Jum'at, 13/4/2018. 